\title{
The Role of Government and Governance in Human Development: A Study of very High Development Economies
}

\author{
Monika Gaur and Ravi Kant
}

\begin{abstract}
The study of human development has witnessed spectacular attention across the globe. The components of the Human Development Index (HDI) such as life expectancy at birth, literacy rate, and GNP per-capita income are the outcome of achieving appropriate economic growth of the nation provided that there are effective government expenditures in the economy. In the era of fiscal consolidation and neo-liberalism, it becomes seemingly essential to revisit the governance role in building human capital, especially in nations with very high human development. The study employed the data of nineteen very high human development countries as per the United Nations Human Development Report, across 2000 to 2016. The data has been collected from the World Bank and the United Nations Development Programme (UNDP) database. The study incorporates the role of government expenditure on various socio-economic aspects like education, health, and the military in the development of human capital, along with the role of Governance. The study deduced the facilitating role of Governance in the developmental process, even in countries with very high human development.
\end{abstract}

Index Terms - Government expenditure, Governance, development, Human Development.

\section{BACKDROP}

The persuasion of measuring economic progress began when Simon Kuznets developed national income and measured Gross Domestic Product (GDP) in the early 1930s. Since GDP only measures the economy's monetary progress by estimating the value of goods and services in a given financial year, it does not reflect the progress in terms of well-being. Several studies identified that the GDP and its components do not reveal the accurate picture of economic development and well-being. Economic development and well-being have a more expansive dimension other than monetary progress. It tries to constitute all dimensions of well-being progress. The progress in terms of human health, education, accessibility to basic amenities, fair and effective Governance, and environmental improvements are essential to measuring well-being. As noted long ago by Robert Kennedy, GDP measures everything, in short, except that which makes life worthwhile. Some economists argue that GDP is not only incapable as an economic index; it also fails to measure social welfare. It does not take into account the quality of the health care system, the level of sanitation,

Published on October 5, 2020.

Monika Gaur, University of Delhi, India.

(e-mail: mgaur177@gmail.com)

Ravi Kant, University of Delhi, India.

(corresponding e-mail: ravinirvana87@gmail.com) and the extent of quality of education [1], [2]. On the other side, GDP tells nothing about sustainability. It fails to estimate the depletion or degradation of natural resources. In 1990, the United Nations Development Program (UNDP) changed the genre of developmental process theory, standard, and the argumentation with the publication of its first annual Human Development Report (HDR) and the unveiling of the Human Development Index (HDI). The formulation of the Human Development concept and measurement is requisite, fulfilling the simultaneous economic growth and human welfare management. As stated by Mr. James Gustav Speth, an UNDP Administrator, sustainable human development is the development that only regenerates the environment rather than destroying it; that empowers people rather than marginalizing them. It gives priority to the poor, enlarging their choices and opportunities and providing for their participation in decisions affecting them. It is the development that is propoor, pro-nature, pro-jobs, pro-women, and pro-children [3]. The concept of Human Development is about expanding human life's well-being, which is not only in terms of financial richness but also concerning different spheres of life, such as better health and education.

The HDI calculated is based on three dimensions:

(i) Life Expectancy at Birth, (ii) knowledge and education, as measured by the adult literacy rate, and (iii) standard of living as indicated by the Gross Domestic Product (GDP) per capita at purchasing power parity (PPP).

The HDI is influenced by many factors of the economy, such as expenditure on education, health, and Governance. The role of Governance in the process of the overall development of the economy was considered a crucial factor in determining HDI's value. The State's effective and sound policies do play a significant role in expanding the developmental process.

\section{LITERATURE REVIEW}

\section{A. Health and Education Expenditure on Human Development}

Few studies have focused on the effects of education, and health expenditure on human development such as Baldacci and Teresa in an article accessed the cost-effectiveness of education and health and found that social programs funded by the government are associated with human development. [4]. A study by Clovis and Nobuko, focusing on health care expenditure with respect to achieving the Millennium Development Goals (MDGs) [5]. They concluded that public expenditure on health care does explain health status. The involvement of government is a relevant factor in 
increasing health care status.

\section{B. Governance and Human Development}

Governance's role is one of the relevant factors to improve the efficiency of public policy and effective delivery of public services, predominantly in social overheads such as education and health. A study by Rajkumar and Swaroop found a significant and robust relationship between the effectiveness of public or government expenditure in health and education on their outcomes with the quality governance at the cross-country level [6]. Some of the studies conducted by De La Croix \& Delavallade, Gupta et al., and Pritchett [7]-[9] found a negative correlation between public expenditure and outcomes both health and education because of variation in efficacy of expenditure and level of corruption. Kaufman [10] found that there is a negative relationship between governance variables and Infant Mortality Rate (IMR).

A Report by UNDP on Human Development in 2002 explicate democratic Governance in human development [11]. It is useful both in terms of form and substance, for the people and by the people. It also explains that democratic Governance with political freedom and a nondiscriminatory framework would expand human development quality. Rhodes, on the other hand, in his study focused on good Governance and its significance [12]. The efficient and effective management of the economy's aggregate resources plays a vital role in producing positive development outcomes. However, no literature has identified the precise relationship between governance quality and its impact on human development. Kaufmann et al. [13] found a significant and robust positive correlation between the quality of Governance and per capita income across the world. They segregated the results into two sections: i) a robust positive correlation from better Governance to higher per capita incomes, and ii) a weak negative correlation moving in the reverse direction from per capita incomes to Governance. World Bank [14] explains that poor and weak budget management and inefficient use of funds in the public sector severed the impact of public expenditure on expected outcomes such as education and health. Further, good Governance in terms of efficient utilization of public resources could improve the economy's health and educational status. If the budget system is inefficient with budget formulation, execution, and monitoring, the outcomes in terms of human well-being would not be attained efficiently even if the government allocates more funds [15]. In another study by World Bank in 2004, if the state has the low administered capacity and weak accountability of service providers towards the citizens, then the public spending on social overheads to eradicate poverty could be inefficient [16]. Thus, good Governance can be accessed both normatively and positively that; how should government manage? Furthermore, how do governments manage in the presence of globalization and liberalization?

\section{SIGNIFICANCE}

The analysis of government expenditure on expanding well-being is vital to see the impact on developmental variables. The impact of economic growth on development can be visualized to see the dissemination process or effective policy implementation. The estimation of the governance gap through the regression analysis Generalised Least Square (GLS) of high and medium human development countries would reflect the effectiveness of determinants of Human Development.

\section{METHODOLOGY}

The study employed the data of nineteen very high human development countries as per the United Nations Human Development Report from the period 1990 to 2016. The regression analysis (Generalised Least Square), where HDI value is the dependent variable (taken in log form) and GDP growth, Military expenditure as a \% of GDP, Government health expenditure as a \% of GDP, out of pocket expenditure per capita, expenditure on primary education as a \% of government's expenditure on education and Rule of law index are the explanatory variables. The data collected from the World Bank and the UNDP database.

\section{ANALYSIS AND INTERPRETATION}

TABLE I: DESCRIPTIVE STATISTICS

\begin{tabular}{|c|c|c|c|c|c|}
\hline Variable & Obs. & Mean & $\begin{array}{l}\text { Std. } \\
\text { Dev. }\end{array}$ & Min & Max \\
\hline GDP growth & 153 & 2.093 & 2.979 & -8.269 & 25.117 \\
\hline $\begin{array}{c}\text { Military } \\
\text { expenditure }\end{array}$ & 153 & 3.405 & 1.314 & .882 & 6.329 \\
\hline $\begin{array}{l}\text { Out of pocket } \\
\text { expenditure }\end{array}$ & 153 & 650.878 & 404.352 & 182.131 & 2325.74 \\
\hline $\begin{array}{c}\text { Health } \\
\text { expenditure }\end{array}$ & 153 & 7.094 & 1.179 & 4.577 & 9.566 \\
\hline $\begin{array}{l}\text { Expenditure on } \\
\text { primary } \\
\text { education }\end{array}$ & 153 & 25.73 & 6.843 & 12.352 & 37.734 \\
\hline Rule of law & 153 & 1.678 & .455 & 0 & 2.1 \\
\hline HDI & 153 & .906 & .024 & .849 & .951 \\
\hline
\end{tabular}


TABLE II: REGRESSION RESULTS

\begin{tabular}{ccccccccc}
\hline Log HDI & Coeff. & St. Err. & t-value & p-value & {$[95 \%$} & Interval] & Sig \\
\hline GDP growth & 0.001 & 0.001 & 1.82 & 0.069 & 0.000 & 0.002 & $*$ \\
Military expenditure & 0.002 & 0.001 & 1.80 & 0.072 & 0.000 & 0.005 & $*$ \\
Health expenditure & 0.009 & 0.002 & 5.25 & 0.000 & 0.006 & 0.013 & $* * *$ \\
Out of pocket expenditure & 0.000 & 0.000 & 7.88 & 0.000 & 0.000 & 0.000 & $* * *$ \\
Expenditure on primary education & 0.001 & 0.000 & 3.53 & 0.000 & 0.000 & 0.002 & $* * *$ \\
Rule of law & 0.016 & 0.003 & 4.60 & 0.000 & 0.009 & 0.023 & $* * *$ \\
Constant & -0.248 & 0.019 & 12.96 & 0.000 & -0.285 & -0.210 & $* * *$ \\
\hline Mean dependent var. & -0.099 & SD dependent var. & 0.027 & & & & \\
Overall r-squared & 0.531 & Number of obs. & 153.000 & & & & \\
Chi-square & 165.343 & Prob. > chi2 & 0.000 & & &
\end{tabular}

$* * * \mathrm{p}<0.01, * * \mathrm{p}<0.05$

$* \mathrm{p}<0.1$

Source: Computed from the World Bank database (2019), https://data.worldbank.org/indicator, and UNDP data (2019). http://hdr.undp.org/en/data.

\section{A. Role of government expenditure}

The study envisages government expenditure on various socio-economic aspects like education, health, and the military. Interestingly, in the era of fiscal consolidation and neo-liberalism, it becomes seemingly essential to revisit the state's role in developing human capital, especially in nations with very high human development. It is often contested that state intervention becomes weak or unnecessary while a nation approaches human capital development's zenith. However, the study is a watershed development in stating that government intervention plays a pivotal cordial role in human capital development. Notably, the government's expenditure remains crucial in all domains considered in the study, i.e., education, health, and military. The regression results shown above are in congruence with the fact that government expenditure significantly escalates human capital development.

\section{B. Role of Governance}

Not just the government but Governance also helps to enhance human development. Governance here, in the present study, is enumerated using the Rule of Law index, which comprehends the nation's ability to adhere to laws. Emphatically, better adherence to laws has significantly escalated human development across nations with very high human development due to the obvious impact of easy enforcement of contracts and reduced social chaos.

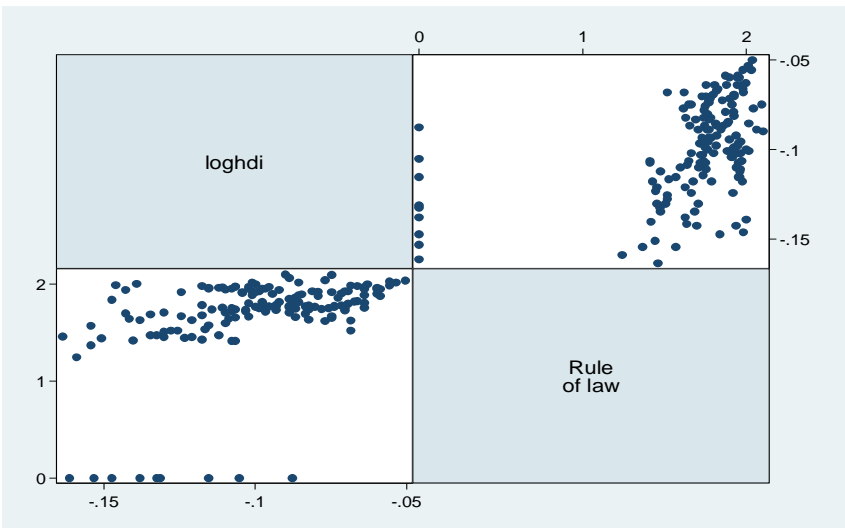

Fig. 1 Scatterplot of Rule of Law and HDI. Source: Author's own calculation.
Figure 1 depicts the scatterplot of the Rule of Law and Human Development Index. The index of the Rule of law varies significantly across the globe (Fig. 2).

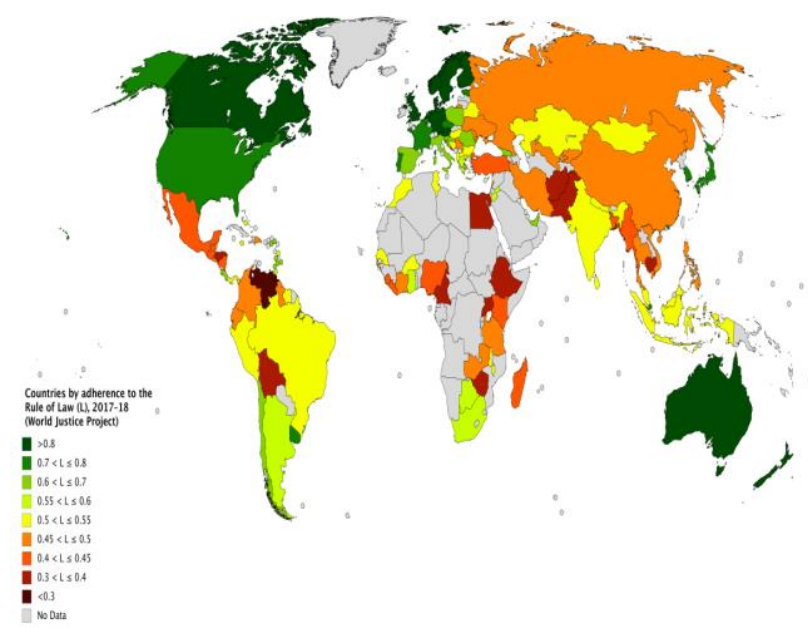

Fig. 2. Rule of Law index across the globe.

Source: Countries by adherence to the Rule of Law according to the 2017-18 World Justice Project report.

\section{CONCLUSION}

The study envisages the pivotal role of government expenditure on the development of human capital. The research refutes the contention that the shrinking role of state and working of invisible hands are the perquisites to higher human burgeons. Interestingly, government expenditure is statistically substantial in escalating human development in very high HDI countries. Further, the study contemplated a significant positive association between effective Governance, i.e., the Rule of law index and Human development. The said relationship ensures inclusive coverage of governmental expenditure.

Moreover, reduced social chaos due to strict and efficient enforceability of contracts also escalates human development at the micro-level. The research implicates the use of government intervention and good Governance, but to an extent, that should not distort markets. Further, Governance should be focused upon to ensure targeted social upliftment. 


\section{REFERENCES}

[1] S. Abdallah, N. Marks, J. Michaelson, N. Steuer, and Thompson, S. "The (Un) Happy Planet Index 2.0. Why Good Lives don't have to Cost the Earth.Centre for Well-Being," New Economics Foundation (NEF), London, UK, 2009.

[2] W. R. Dipietro and E. Anoruo, GDP per capita and its challenges as measures of happiness", International Journal of Social Economics, 33(10), 698-709.

[3] United Nations Development Programme, "Human Development Report", Oxford University Press: New York: 1994.

[4] E. Baldacci, M. Teresa and Luizde M., "More on The Effectiveness of Public Spending on Health Care And Education", Journal of International Developmentt, 2003.

[5] C. F, Nobuko," Impact of Health Expenditure on Achieving the Health-Related MDGs", MPDD Working Papers, August 2011.

[6] A. S. Rajkumar and V. Swaroop. "Public Spending and Outcomes: Does governance matter?" Journal of Development Economics, 86, 96-111, 2008.

[7] De la Croix, D and C. Delavallade. "Growth, public investment and corruption with failing institutions". Society for the Study of Economic Inequality, Working paper, 2006.

[8] S. Gupta, M. Verhoeven, and Erwin. T. "Does higher government spending buy better results in education and health care"? International Monetary Fund, Working Paper 99/21, Washington, 1999.

[9] L. Pritchett, 'Mind your P's and Q's: the cost of public investment is not the value of public capital". Policy research working paper 1660. Development Economics Research Group, World Bank, Washington, D.C, 1996.

[10] D, Kaufmann, "Corruption, governance and security: challenges for rich countries and the World", 2004. Available at SSRN:https://ssrn.com/abstract=605801 orhttp://dx.doi.org/10.213 9/ssrn.605801

[11] United Nations Development Programme. Human Development Report, Oxford University Press: New York, 2004.

[12] R. A. W. Rhodes. "The New Governance: Governing Without Government", Political Studies, 44(4): 652-67, 1996.

[13] D. Kaufmann, A. Kraay, and Massimo, M, "Governance Matters III: Governance Indicators for 1996- 2002", The World Bank, Washington, D.C, 2003.

[14] World Bank, "Making services work for poor people. World development report ". World Bank, Washington, D.C, 2003.

[15] World Bank, "Budgeting and Budgetary Institutions, Public sector governance and accountability series", edited by Anwar Shah, 2007.

[16] World Bank, "Making services work for poor people". World development Report. World Bank, Washington, D.C, 2003. 